\title{
In-Service Teachers' views and conceptions on culture and mathematics education in rural schools.
}

\author{
Mr.Jonatan Muzangwa, Dr.Andrew Chindanya \\ Great Zimbabwe University, Faculty of Education, Department of Curriculum Studies \\ jonamuz@gmail.com \\ Great Zimbabwe University ,Faculty of Education, Department of Teacher Development \\ andychindanya@gmail.com
}

\begin{abstract}
The teaching of culture and heritage studies is the flagship of Great Zimbabwe University. This present study is investigating preliminary views and conceptions of in-service teachers on culture and mathematics education. Data was collected through a questionnaire survey on all 27 teachers who majored in mathematics education. The group was considered small enough to render sampling unnecessary. It was observed that a good part of students were aware of the significance of the role of culture on mathematics education whilst some were not very sure how culture played a role in the field of mathematics. We recommend the school curriculum to implement culture-oriented mathematics education that ensures the survival of African culture.
\end{abstract}

Key words: Culture, mathematics education, rural school

\section{Council for Innovative Research}

Peer Review Research Publishing System

Journal: INTERNATIONAL JOURNAL OF RESEARCH IN EDUCATION METHODOLOGY

Vol .6, No.2

www.ijrem.com , ijremeditor@gmail.com 


\section{INTRODUCTION}

Some people might think mathematics is a place-free subject which can be taught anywhere and anytime, but a good teacher is sensitive to the environment in which he / she is operating. For example, if one wanted to introduce the concept of a "cone" in the teaching of solid shapes in a rural context and the other wanted to do the same in an urban context, the examples they would use in a rural context and in an urban context could be very different. Similarly, if a teacher wanted to introduce the concept of common fractions at primary school level, the tangible objects the teacher could use in a rural context were likely to differ from those that could be used in an urban context. Research on these issues established that the outcomes of the process of teaching and learning depended on time and place (Levitas,1974). Various contextual examples could be cited but the general trend was that rural setups provided their own examples while urban setups also provided their own examples. Rural schools, however, tended to be marginalised in terms of teaching resources. This scenario motivated the researchers to study the culture of teaching and learning mathematics in rural schools.

Alasuutari(1995) defines culture as "...collective subjectivity - that is a way of life or outlook adopted by a community or a social class." Bogden and Bilken(1992) seem to enlarge this definition when they postulate that "...culture embraces what people do, what people know, and things that people make and use." Culture thus involved a wide variety of things which constituted the characteristics of a particular group. A way of life is a way of doing things. The way of doing things tended to vary from place to place, or rather from community to community. It can thus be said communities have different cultural knowledge.

Neumann(1997) defines cultural knowledge as that which includes symbols, songs, sayings, facts, ways of behaving, and objects (e.g. telephones and newspapers). People learned culture partly by watching television, listening to parents, playing games and observing others. Because of the different materials that could be found in rural and urban setups, rural culture and urban culture tended to differ.

Teachers, being propagators of culture in their own right, need to be sensitive to matters of culture. Some teachers of mathematics were unconvinced that multicultural considerations were of any real relevance to their subject. The view was often expressed that of all disciplines, mathematics was the most culture - free. However, Costello (1991) has long argued that "...teachers need to devise examples and illustrations, within the National Curriculum framework, which relate to the cultural background of pupils." The teaching approaches relating to mathematics in rural schools therefore needed to be different from those used in urban setups.

In the context of this research, a rural school is one which is located in a rural area, excluding rural boarding schools and schools in peri-urban areas while an urban school is one that is located in towns and cities

\section{LITERATURE REVIEW}

A literature review was undertaken to illuminate issues surrounding ethno-mathematics

\section{Ethno-mathematics}

The present study was guided by the works of Ubitaran D'Ambrosio and Paulus Gerdes on ethno-mathematics. Gerdes (2002) describes ethno-mathematics (or ethno-mathematicology) as a relatively new area of research. It might be described as the study of mathematical ideas and activities as embedded in their cultural context. D'Ambrosio (1984,1985) has used the expression ethno-mathematics to refer to forms of mathematics that vary as a consequence of being embedded in cultural activities whose purpose is other than doing mathematics. Everyday activities included building houses, exchanging money, weighing products and calculating proportions for a recipe involving numbers, calculations , and precise geometrical patterns. These applications of mathematics often looked different from those used in school . In the kitchen we often measured volumes with spoons and cups, whereas in school activities students typically measured volume in litres and cubic metres. Everyday mathematics also varied sequentially across countries because of differences in the numeration systems used, for example , or the devices used for calculating. These differences might be perceived as deep or surface structure differences depending on what views one held of mathematical knowledge.

As views of mathematics as "culture free" and "universal" have been rather dominant in academia, the idea of ethnomathematics has emerged relatively late. D' Ambrosio launched his ethno-mathematical programme in the 1970s (D'Ambrosio, 1985, 1997), as a methodology to track and analyse the processes of generation, transmission, diffusion and institutionalisation of mathematical knowledge in diverse cultural systems. He developed his ideas inspired by a reflection about major problems of mathematics education in the Third World. In contrast to "academic mathematics," that is the mathematics which is taught and learned in schools and universities, D'Ambrosio called ethno-mathematics "...the mathematics which is practised among identifiable cultural groups, such as national -tribal societies, labour groups, children of a certain age bracket, professional classes and so on" (D'Ambrosio, 1985).

\section{The rationale of teaching and learning mathematics through culture}

From the above illumination of the notion of ethno-mathematics, it is quite clear that in the African societies there were lots of cases where mathematics was identified implicitly with cultural activities. Ethno-mathematics could be viewed as a research programme in the history and philosophy of mathematics, with pedagogical implications, focussing on the art and techniques of explaining, understanding and coping with different socio-cultural environments. The main goal of culture and mathematics, it could be argued, was to promote the following sub-concepts: indigenous mathematics, sociomathematics of Africa, informal mathematics, mathematics in the (African) socio -cultural environment, oppressed 
mathematics, non-standard mathematics, hidden or frozen mathematics, folk mathematics and implicit and nonprofessional mathematics (Gerdes, 2002).

\section{RESEARCH DESIGN}

A Case study of a group of Bachelor of Education In-Service students specialising in Mathematics Education at Great Zimbabwe University was conducted. The students were offered a course in Ethno-mathematics. One of major goals of the University was to promote the study of Culture and Heritage in Southern Africa. This research was carried out just before the students had taken the course of Ethno-mathematics. A questionnaire was used to gather the required information. This questionnaire was completed by a group of twenty- seven students. The data generated from the questionnaire was used to analyse the views and conceptions of teachers concerning culture and mathematics education. The critical issue in this research was to find the intersection of culture, mathematics education and rural background. It emerged from the research that one view was that mathematics teaching and learning was place-specific and, in particular may perhaps should look rather different from place to place. The following are the issues which are likely to emerge in this investigation : teaching, policy ,learning and culture. Questions concerning these four categories have been included in the questionnaire. The results of the research are significant in probing the pre-concepts which are held by students before they have taken the course of Ethno-mathematics.

\section{DATA COLLECTION AND RESULTS}

Data was collected from the responses of 27 teachers specialising in Mathematics in the BEd in-service degree programme at Great Zimbabwe University. Each student completed a questionnaire with two sections, namely personal details and culture and mathematics education.

\section{Results}

Table1. Background information of respondents

\begin{tabular}{|l|l|l|l|l|l|l|l|}
\hline Gender & Male=14 & Female=13 & & & & \\
\hline Province & Masvingo=15 & Midlands=2 & Mat.South=3 & Mat.North=2 & Mash.Central=3 & Harare=1 & Mash.West=1 \\
\hline $\begin{array}{l}\text { Age } \\
\text { Lochool }\end{array}$ & Rural=20 & Urban =4 & $\begin{array}{l}\text { Peri- } \\
\text { urban=2 }\end{array}$ & 30-39=18 & Farm=1 & & \\
\hline $\begin{array}{l}\text { School } \\
\text { type }\end{array}$ & Day=25 & Boarding=2 & & & & & \\
\hline
\end{tabular}

Table 2. Culture and Mathematics Education

\begin{tabular}{|c|c|c|c|c|c|}
\hline & QUESTION & AGREE & DISAGREE & $\begin{array}{l}\text { NOT } \\
\text { SURE }\end{array}$ & TOTAL \\
\hline \multirow[t]{3}{*}{ CULTURE } & $\begin{array}{l}\text { Mathematics is a culture free } \\
\text { subject }\end{array}$ & 21 & 5 & 1 & 27 \\
\hline & $\begin{array}{l}\text { Culture plays a significant role in } \\
\text { the teaching of mathematics }\end{array}$ & 18 & 7 & 2 & 27 \\
\hline & $\begin{array}{l}\text { Culture plays a significant role in } \\
\text { the learning of mathematics }\end{array}$ & 22 & 2 & 3 & 27 \\
\hline POLICY & $\begin{array}{l}\text { Mathematics syllabi have a policy } \\
\text { on culture and mathematics } \\
\text { education }\end{array}$ & 15 & 8 & 4 & 27 \\
\hline \multirow[t]{2}{*}{ LEARNING } & $\begin{array}{l}\text { Students/ Children learn much of } \\
\text { the mathematics outside schools }\end{array}$ & 19 & 7 & 1 & 27 \\
\hline & $\begin{array}{l}\text { The learning of mathematics } \\
\text { varies between different cultures }\end{array}$ & 18 & 7 & 2 & 27 \\
\hline
\end{tabular}




\begin{tabular}{|l|l|l|l|l|l|}
\hline TEACHING & $\begin{array}{l}\text { The use of games in } \\
\text { mathematics teaching is an } \\
\text { example of culture and } \\
\text { mathematics education } \\
\text { intersection }\end{array}$ & 27 & 27 & \\
\cline { 2 - 5 } & $\begin{array}{l}\text { Problem -Solving method is an } \\
\text { application of culture and } \\
\text { mathematics education }\end{array}$ & 23 & 3 & 1 & 27 \\
\hline TOTAL & 163 & 39 & 14 & 216 \\
\hline
\end{tabular}

\section{DATA ANALYSIS}

\section{Background of respondents}

The population under consideration was well represented by almost a uniform distribution of male and female respondents who came from the seven provinces of Zimbabwe. The age distribution is almost normal since the $66 \%$ of the sample fall in the age range of 30-39. Again a majority of respondents work in the rural community with almost all schools falling in the category of day -schools. These teachers have more than two years of service in the teaching field since they are all on Staff Development Leave and their highest qualification at present is a Diploma in Education.

\section{Culture and mathematics education}

Considering Table2 above, it is quite clear that the majority of the respondents which can be summarized by $75 \%$ of the response agree on the significance of the role of culture on mathematics education. Only $25 \%$ disagree or are not sure on whether culture plays a key role in mathematics education. All the respondents concurred with the fact that the method of games is clearly a good example of culture and mathematics education. This is true because traditional African games such as nhodo and pada are frequently used in primary schools to introduce the concepts of addition and subtraction as well as drawing of simple shapes such as rectangles and circles.

\section{RECOMMENDATIONS}

Teaching: The main agent for the success of mathematics education in the rural areas is the teacher. Jaworski (1994) argues that "a teacher's personal philosophy or view of the nature of mathematics ,and its learning and teaching, influences very considerably the way a teacher teaches." Instructional practices are derived from philosophy of education, psychology of education and sociology of education. We recommend that teachers be very cognisant of the culture of the community in which they work so that mathematics, taught in a cultural context, can be more easily grasped and more deeply appreciated by the learners. If cultural context is recognised, chances of parental involvement in the teaching and learning of their children is enhanced. If parental involvement in their children's education is promoted, children learn more effectively (Chindanya, 2011). When teachers receive in-service training with focus on ethno-mathematics, we can anticipate high pass rates in mathematics in the rural areas. Usually students in the rural areas face difficulties when they are being assessed. Mathematics examination questions usually from Zimbabwe Schools Examination Council have examples which are urban context-based. Students in rural schools have difficulties in solving such type of problems.

Policy:_One of the goals of curriculum policy in Zimbabwe is to preserve Zimbabwean culture and heritage through education. The Secretary`s Circular No. 3 of 2002 has no specific policy for rural schools concerning mathematics education. We recommend the school curriculum to implement culture-oriented mathematics education that promotes the survival of African culture.

Learning: Teachers of mathematics quickly discover that learning does not take place automatically following what they consider to be their most outstanding lessons. This is because adults also place their own interpretations on, and are selective in what they internalize from ,conversations, experiences and events. The quality of interaction between the learner and environment, of which the teacher may form an important element, must have considerable effect on quality of learning. It is imperative for teachers of mathematics in rural areas to make use of teaching and learning aids that can be readily found in the environment to foster mastery of concepts by the learners. Using the local environment to teach mathematics is important because it helps students make connections between the world around them and the school. It also helps students understand their environment and see how mathematics is used in real life. What are the teaching aids and resources ideal for rural schools ? Teacher should task pupils to find the following objects which can used to teach mathematics and are readily available in the environment: sticks, corks, bottle tops, matchboxes, envelopes, shells, beads, pebbles, buttons, old coins ,seeds ,pots ,twigs ,clay ,tins ,bottles, art and craft pieces of work and any other objects. Usually for rural secondary schools we expect the use of locally found or produced teaching aids to be used in the classroom. There is also need to link the content being taught with the local environment. When the content is on consumer arithmetic the teacher should cite examples of transactions which are done in the local environment rather than use examples which are abstract to the rural student. Orton and Wain (1994) define mathematics in daily life as "survival mathematics." Students should therefore learn mathematics which can help them to solve mathematical problems at home. Selinger (1995) argues that "the application of mathematics in contexts which have relevance and interest is an 
important means of developing pupils understanding and appreciation of the subject and of those contexts." Transfer of learning is thus facilitated. This argument is the basis for the rationale of cross-curricular work.

Culture: As we have already defined culture as what people do, what people know, and things that people make and use. The teacher's task is to find the cultural activities done in the local community which are useful in the teaching of mathematics. The following are some of cultures that can be brought into the classroom: buildings and architecture, weaving and cloth, sculptures and paintings, weights and measures, games played in the community, number systems, bartering systems and finger counting systems. Gerdes (1985), one of the main writers in the field of ethno-mathematics, argues that African mathematicians "could well have developed Pythagoras' Theorem before Greek times , but that ways of recording ideas would not have enabled that information to have been perpetuated." This was said in reference to the study of ethno-mathematics. It is also critical to know the level of knowledge the community at large has on mathematics education. Bringing the cultural knowledge of the community into the classroom is important because it breaks down the barriers between home and school and thus render parents relevant to. It values the mathematics that is going on in the community. It makes links between the mathematics that is used in the community and the school syllabus. It shows that the community is a good resource for mathematics and it makes school mathematics more relevant to students.

\section{Conclusion}

This preliminary research is not meant to prove or disapprove any theory, but it can easily form a basis for interrogating such theories as the deficit theory which make what some regard as preposterous claims in relation to the so called deprived communities. The central idea is to get as much information as possible from teachers, pupils ,parents and educators in the rural areas concerning how best mathematics can be taught in a rural setup.

\section{REFERENCES}

[1] Alasuutari, P. 1995. Researching Culture : Qualitative method and Cultural Studies (pp23-37) SAGE Publications Ltd. University of Tampere, Finland.

[2] Bogdan, R.C. and Biklen, S.K. 1992. Qualitative Research For Education: An

Introduction to Theory and Methods: Allyn and Bacon.Pearson Education Ltd. U.K.

[3] Costello ,J. (1991) : Teaching and Learning Mathematics 11-16: Harcourt PublishersLtd. London and New York.

[4] D'Ambrosio ,U(1985): Ethnomathematics and its place in the history and pedagogy of mathematics. International Studygroup of Ethnomathematics. For the Learning of mathematics 5(1):44-48, 1985a

[5] Flick, U. (2002) :An Introduction to Qualitative Research :Sage Publications, London

[6] Gerdes ,P.(1985): Conditions and strategies for emancipatory mathematics education in undeveloped countries: For the Learning of mathematics 5(3) : 15-20, 1985a New York

[7] Gerdes ,P.(2002):Ethnomathematics as a new research field, illustrated by studies of mathematical ideas in African history.Mozambican Ethnomathematical Research Project.Maputo

[8] Halfpenny,P.(1982):Positivism and Sociology:Explaining Social life : Allen \& Urwin ,London.

[9] Hiebert J. \& Stigler, J.(1999) :The Teaching Gap. Havard Educational Review, New York

[10] Jaworski,B.(1991)Interpretations of a constructivist philosophy in teaching mathematics: Published PhD_Open University , UK

[11] Levitas ,M.(1974) Marxist Perspectives in the Sociology of Education :_Erich Honecker Cross Examined edited and translated by Maurice Levitas (1992), London ,U.K.

[13] Neumann,W.L. (1997); Social Research Methods : Qualitative and Quantitative Approaches: Allyn and Bacon. Pearson Education Ltd. U.K.

[14] Orton ,A \& Wain ,G.(1994) :Issues in Teaching Mathematics:National Council of Teachers of Mathematics , London \& New York

[15] Selinger ,M.(1995):Teaching Mathematics:National Council of Teachers of Mathematics ,London \& New York

[16] Waters,M;Howley,C. \&Schultz J.(2005): An Initial Agenda for Rural Mathematics Education:Journal of Appalacian Studies Volume 14 No.1-2 pp125-144, Ohio University. 


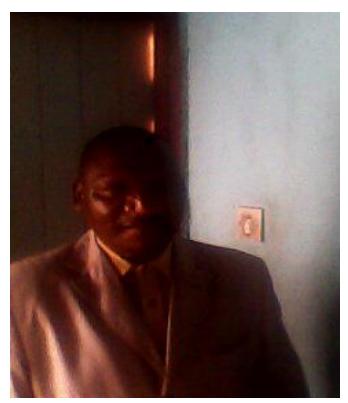

Mr.Jonatan Muzangwa is a holder of Mater of Mathematics Education (UZ) and is currently a lecturer in the Department of Curriculum Studies at Great Zimbabwe University.

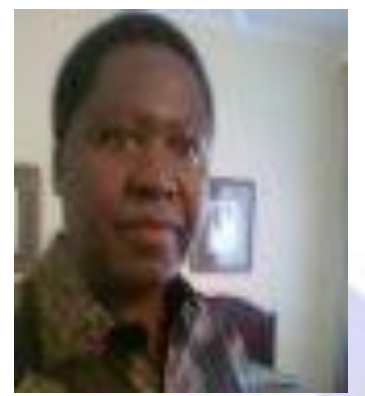

Dr.Andrew Chindanya is a holder of Doctor of Philosophy in Education (UNISA) and is currently Dean of the Faculty of Education at Great Zimbabwe University. 